Article

\title{
Biological Waste Management in the Case of a Pandemic Emergency and Other Natural Disasters. Determination of Bioenergy Production from Floricultural Waste and Modeling of Methane Production Using Deep Neural Modeling Methods
}

\author{
Jakub Frankowski *, Maciej Zaborowicz * (D), Jacek Dach, Wojciech Czekała and Jacek Przybył \\ Institute of Biosystems Engineering, Poznan University of Life Sciences, Wojska Polskiego 50, \\ 60-637 Poznan, Poland; jacek.dach@up.poznan.pl (J.D.); wojciech.czekala@up.poznan.pl (W.C.); \\ jacek.przybyl@up.poznan.pl (J.P.) \\ * Correspondence: jakub.frankowski@up.poznan.pl (J.F.); maciej.zaborowicz@up.poznan.pl (M.Z.)
}

Received: 15 April 2020; Accepted: 9 June 2020; Published: 11 June 2020

\begin{abstract}
In relation to the situation caused by the pandemic, which may also take place in the future, there is a need to find effective solutions to improve the economic situation of the floristry industry. The production and sale of flowers is time-consuming and long-term. Therefore, any information that causes the impossibility of selling the plants will result in a reduction of profitability or bankruptcy of such companies. Research on rationally utilizing biowaste from plant cultivation as well as unsold flowers for environmental protection and effective use of their potential as a raw material for bioenergy production were examined in this article. The aim of this study was to analyze the energetic potential of the biodegradable fraction of waste from floriculture. The trials included floricultural waste containing the stems, leaves and flowers of different species and hybrid tulips (Tulipa L.), roses (Rosa L.), sunflowers (Helianthus L.) and chrysanthemums (Dendranthema Des Moul.). Their biogas and methane production as well as heat of combustion were determined experimentally. The calorific value was calculated on the basis of results from selected floricultural waste and its chemical composition. The biogas production was tested on different levels of plant material fragmentation (chaff, macerate) in fermentation processes with two ranges of temperature (meso- and thermophilic fermentation). The presented results show that the highest calorific values were determined for dry stems of roses $(18,520 \mathrm{~kJ} / \mathrm{kg})$ and sunflowers $(18,030 \mathrm{~kJ} / \mathrm{kg})$. In turn, the lowest were obtained for dried chrysanthemums and tulips, for which the heating value reached $15,560 \mathrm{~kJ} / \mathrm{kg}$ and $15,210 \mathrm{~kJ} / \mathrm{kg}$. In addition, based on one ton of the fresh mass of biowaste from floriculture, the largest biogas production including the control was obtained from the chrysanthemum chaff by mesophilic anaerobic digestion. Moreover, the largest volume of methane was received by thermophilic anaerobic digestion of roses. The highest content of biomethane (56.68\%) was reached by thermophilic fermentation of roses. The energy production of the analyzed substrates was also calculated, based on the amount of biogas produced in the containers for anaerobic digestion. Additionally, a deep neural network model, which predicted the production of methane gas, was created. Owing to the properties of the network, the level of significance of variables used for modelling and prediction of biogas production was determined. The neural modelling process was carried out with the use of the $\mathrm{H}_{2} \mathrm{O}$ program.
\end{abstract}

Keywords: biowaste; energy potential; biogas; solid biofuels; energy value; artificial neural networks; deep learning; neural modeling 


\section{Introduction}

During natural disasters like a pandemic and any other crises, many industries report losses. One of these sectors of the economy is gardening and horticulture. Agricultural and horticultural production cannot be stopped overnight. Despite the health risks, the flowers are produced and unfortunately do not find buyers among the citizens. It is estimated that, in the Netherlands, 400 million tons of unsold flowers were destroyed, including 140 million tons of tulips, during only one month (March 2020) [1]. This problem also affects other countries and it results in wasting huge amounts of biomass from the floriculture industry.

In the meantime, the growing demand for energy necessitates a number of actions leading to every country's self-sufficiency in the area of electricity and heat production. The development of ecological ways of obtaining biomass, which is feedstock for the production of bioenergy, is a priority in the European Union [2]. In addition, the use of waste biomass for this purpose would allow simultaneous fulfillment of the provisions of this directive and reduce the amount of waste not subjected to rational management.

Floriculture is predominantly defined as species and cultivars produced by retail greenhouses, cut flower wholesalers and foliage plant brokers [3]. In this article, the term "floricultural waste" has been narrowed down and refers to the parts of plants that are waste from greenhouses, plantations, florists, stock exchanges and other places where the cut flowers are being traded.

Due to the multitude of plants grown for cut flowers, floricultural waste is characterized by a very large diversity, both in terms of morphology and physical and chemical properties. Stalks and leaves are always the largest part of the waste generated in such places. In addition, they also include faded flowers.

There are no studies in the literature showing the quantitative and qualitative composition of waste generated in florists. Some researchers proved that floricultural waste is used in composting, vermicomposting or green manuring by only 8.33 percent of farmers [4]. All the more, that kind of waste has not thus far been described in terms of its suitability for energetic purposes. However, all sorts of floricultural waste may be transformed into biofuel, because this feedstock contains biodegradable organic matter to decrease the environmental impact of floricultural activities [5]. It may be a good source for pellets, briquettes or biogas production if it does not contain detergents, antiseptics, antibiotics and other inhibitory compounds, which are toxic to fermentation bacteria [6-8]. It seems that this type of feedstock should be rapidly decomposed during anaerobic digestion processes by specialized bacteria [9-11].

The aim of this study was to analyze the energetic potential of the biodegradable fraction of waste from floriculture. The trials included floricultural waste containing the stems, leaves and flowers of different species and hybrid tulips (Tulipa L.), roses (Rosa L.), sunflowers (Helianthus L.) and chrysanthemums (Dendranthema Des Moul.).

Their biogas and methane production as well as heat of combustion were determined experimentally. The heating value was calculated on the basic results of selected floricultural waste $[12,13]$. The biogas production was tested on different levels of plant material fragmentation (chaff, macerate) in fermentation processes with two ranges of temperature (under meso- and thermophilic conditions of fermentation). The energetic production of the analyzed substrates was also calculated based on the amount of biogas produced in the containers for anaerobic digestion.

Artificial intelligence methods, including artificial neural networks, are readily used to model natural phenomena which are characterized by high complexity. They allow the analysis of data of many variables and conclusions about the phenomenon on the basis of developed models. The neural models are used by scientists from such fields as agricultural engineering, including issues related to the production of energy from renewable sources. They are used, among other things, for neural analysis of the quality of agri-food products, such as fruits and vegetables, cereal grains, and meat [14-22]. It is also possible to use neural modeling methods to evaluate the composting process [23-29]. In addition, 
artificial neural networks can be used to predict the prices of agricultural products on commodity markets [30,31] and to forecast energy production from solar systems [32,33].

Deep neural modelling is a relatively new technique that is increasingly being used in the life sciences. It differs from traditional techniques in terms of speed and accuracy. In 2006, the Hinton team [34] presented a new method of teaching artificial neural networks. Deep learning is a class of machine learning methods for hierarchical (deep) models with non-linear layers. The idea of deep learning is to pre-train the network (so-called pre-training), and in the next step to learn how to network in a supervised way. In neural modelling methods used so far, it has been necessary to have a large set of data to correctly carry out the learning process. In deep learning methods, a large data set is not required. Networks have the ability to share and reduce data sets. This means that it is not necessary to perform many repetitions in empirical studies. However, this property does not affect the quality of the generated model.

Since 2010, one can notice a significant increase in interest in deep learning techniques, and, since 2012, a significant reduction in the inaccuracy of researchers' networks using new methods. According to industry magazines, the pattern recognition error through a DNN (Deep Neural Network) is about $5 \%$, which is at the level of error committed by humans [35]. An important property of deep networks is the ability to act and process data in real time.

\section{Materials and Methods}

\subsection{Raw Material for the Bioenergy Production}

The analysis aimed at determining the energy potential of selected floriculture waste as feedstock for biogas production included stalks, leaves and flowers of various species and hybrid forms of tulips, roses, sunflowers and chrysanthemums. Leaves constituted the largest percentage of waste, followed by stems and flowers.

Before starting the research, the biomass was mechanically ground to increase the availability of organic substances for fermenting microorganisms. Chains with a length of biomass pieces up to about $5 \mathrm{~mm}$ and tulip macerates with a smaller particle size were obtained.

The research on the process of mesophilic anaerobic digestion concerned chaff and macerate from tulips and chaff from roses, sunflowers and chrysanthemums. In the other type of fermentation-thermophilic - the energy potential of the same chaff with roses, sunflowers and chrysanthemum was analyzed to determine the effect of temperature on the performance of individual feedstock.

In order to properly conduct the experiments to determine the calorific value of the feedstock, the raw material was thoroughly broken up. For this purpose, the test material was cut into small pieces and then ground with a mortar and, subsequently, with a coffee grinder. A homogeneous mass was prepared from each flower species.

\subsection{Methods of Calorific Value Determination}

To determine the energetic potential of floriculture waste, laboratory analyses were done following Polish standards PN-81/G-04513.

The experiments were carried out on a KL-12Mn calorimeter. The heat of combustion $\left(Q_{s}\right)$ of each feedstock was calculated according to the formula:

$$
\mathrm{Q}_{\mathrm{s}}=\frac{\mathrm{C} \cdot\left(\mathrm{D}_{\mathrm{t}}-\mathrm{k}\right)-\mathrm{c}}{\mathrm{m}}
$$

where:

C-heat capacity of the calorimeter (13 $122 \mathrm{~J} / \mathrm{K})$,

$\mathrm{D}_{\mathrm{t}}$-general increase in the main period temperature $(\mathrm{K})$,

$\mathrm{k}$-correction for calorimeter heat exchange with surroundings $(\mathrm{K})$, 
c-heat correction emitted during wire burning $(6698,9 \mathrm{~J} / \mathrm{K})$,

$\mathrm{m}$-mass of solid fuel sample (g).

For each feedstock, five repetitions were made, and then the arithmetic mean was calculated.

The calorific value $\left(Q_{w}\right)$ of each feedstock was subsequently calculated from the following formula:

$$
\mathrm{Q}_{\mathrm{W}}=\mathrm{Q}_{\mathrm{S}}-24.42 \cdot\left(\mathrm{W}_{\mathrm{a}}+8.94 \cdot \mathrm{H}_{\mathrm{a}}\right)
$$

where: $\mathrm{Q}_{\mathrm{s}}$ - heat of combustion of the analyzed sample under analytical conditions $(\mathrm{J} / \mathrm{g}), \mathrm{W}_{\mathrm{a}}$ - moisture content in the analyzed sample (\%), $\mathrm{H}_{\mathrm{a}}$-hydrogen content of each sample (\%) [36-39].

\subsection{Methods of Biogas and Methane Production}

At the beginning, chemical and physical analyses of floriculture waste were made. The total solids content (TS, dried mass) was measured within the Polish standard PN-75C-04616/01. The volatile total solids content (VTS, organic dried mass) was analyzed in accordance with the PN-Z-15011-3 standard [11-13].

The dry matter content was calculated in the Microsoft Excel spreadsheet according to the formula:

$$
\operatorname{TS}[\%]=\frac{\mathrm{m}_{2}-\mathrm{m}_{1}}{\mathrm{~m}_{0}} \cdot 100 \%
$$

where: $\mathrm{m}_{0}$-fresh mass of feedstock $[\mathrm{g}], \mathrm{m}_{1}$-mass of water $[\mathrm{g}], \mathrm{m}_{2}$-mass of the dried feedstock + mass of the dish $[\mathrm{g}]$.

To determine the organic dry matter content in floriculture waste, the parameter calculations were made according to the following formula:

$$
\operatorname{VTS}[\%]=\frac{m_{c}-\left(m_{b}-m_{a}\right)}{m_{c}} \cdot 100 \%
$$

where: $\mathrm{m}_{\mathrm{a}}$-mass of water $[\mathrm{g}], \mathrm{m}_{\mathrm{b}}$-mass of feedstock after combustion + mass of water $[\mathrm{g}], \mathrm{m}_{\mathrm{c}}$-mass of the dried feedstock $[\mathrm{g}]$.

The Hydraulic Retention Time (HRT) of floriculture waste was tested experimentally, based on the following standards: DIN 38414/S8 and VDI 4630. The biogas yield was recorded under standard conditions [11,40-43].

The experiments on biogas production were run in a multichamber digester for anaerobic digestion. The capacity of each individual glass biofermenter was $2 \mathrm{dm}^{3}$. The biogas production was recorded daily with an accuracy to $0.01 \mathrm{dm}^{3}$. The criterion for the completion of the measurement was the daily production below $1 \%$ of the total accumulated biogas [11,40-44].

During the course of the anaerobic digestion process, $\mathrm{pH}$ and conductivity were tested daily. In addition, the redox potential was measured every second day for tulips and roses. The tests were performed with the Elmetron CPC-411 meter. The reaction was measured in accordance with PN-90/C-04540/01, and conductivity based on PN-EN 27888: 1999.

The charge in the bioreactors was mixed for 60 seconds every $24 \mathrm{~h}$. The daily production of biogas was measured by reading on a scale placed on the cylinder in which it accumulated. The MSMR-4/BIO type system was used to check the biogas chemical composition. The content of $\mathrm{CH}_{4}, \mathrm{CO}_{2}, \mathrm{O}_{2}, \mathrm{NH}_{3}$ and $\mathrm{H}_{2} \mathrm{~S}$ was determined using a gas analyzer.

The usefulness of selected floricultural waste for energetic purposes was assessed based on the amount of feedstock. The produced biogas and methane volumes $\left(\mathrm{m}^{3}\right)$ were calculated using the following formulae [11,40]:

$$
\mathrm{V}_{\mathrm{b}}=\mathrm{B}_{\mathrm{e}} \cdot \mathrm{M}_{\mathrm{s}}
$$


where: $\mathrm{V}_{\mathrm{b}}$-produced biogas volume $\left(\mathrm{m}^{3}\right), \mathrm{B}_{\mathrm{e}}$ - biogas production of the feedstock $\left(\mathrm{m}^{3} / \mathrm{Mg}\right), \mathrm{M}_{\mathrm{s}}$-mass of the feedstock $(\mathrm{Mg})$. Hence:

$$
\mathrm{V}_{\mathrm{CH}_{4}}=\mathrm{V}_{\mathrm{b}} \cdot \mathrm{C}_{\mathrm{CH}_{4}}
$$

where: $\mathrm{V}_{\mathrm{CH} 4}$-produced methane volume $\left(\mathrm{m}^{3}\right), \mathrm{V}_{\mathrm{b}}$-produced biogas volume $\left(\mathrm{m}^{3}\right), \mathrm{C}_{\mathrm{CH} 4}$-methane concentration in produced biogas (\%).

\subsection{Energy Calculations}

The utility of waste from floriculture for energetic purposes was determined based on the amount of each feedstock biogas and methane production. Moreover, the realizable amount of electricity and the amount which could be produced during combustion of the biogas produced from this feedstock in cogeneration system were calculated using the following formulae [11,40]:

$$
\mathrm{E}_{\mathrm{E}}=\mathrm{V}_{\mathrm{CH}_{4}} \cdot \mathrm{Ra}_{\mathrm{CH}_{4}} \cdot \eta_{\mathrm{E}}
$$

where: $E_{\mathrm{E}}$-produced energy amount $(\mathrm{MWh}), \mathrm{V}_{\mathrm{CH} 4}$-produced methane volume $\left(\mathrm{m}^{3}\right)$, $\mathrm{Ra}_{\mathrm{CH} 4}$ - methane energy production ratio $\left(0.00917 \mathrm{MWh} / \mathrm{m}^{3}\right), \eta_{\mathrm{E}}$-electrical production of the cogeneration unit (for this calculation, $44 \%$ electrical efficiency was assumed). Likewise:

$$
\mathrm{E}_{\mathrm{H}}=\mathrm{V}_{\mathrm{CH}_{4}} \cdot \mathrm{Ra}_{\mathrm{CH}_{4}} \cdot \eta_{\mathrm{T}}
$$

where: $\mathrm{E}_{\mathrm{H}}$-produced heat amount $(\mathrm{MWh}), \mathrm{V}_{\mathrm{CH} 4}$ —produced methane volume $\left(\mathrm{m}^{3}\right), \mathrm{Ra}_{\mathrm{CH} 4}$-methane energy efficiency ratio $\left(0.00917 \mathrm{MWh} / \mathrm{m}^{3}\right), \eta_{\mathrm{E}}$ - heat production of the cogeneration unit (for this calculation: $45 \%$ heat efficiency was assumed). Furthermore, the result was also expressed in (GJ):

$$
\mathrm{E}_{\mathrm{H}_{\mathrm{GJ}}}=\frac{\mathrm{E}_{\mathrm{H}}}{0.278}
$$

where: $\mathrm{E}_{\mathrm{HGJ}}$-produced heat amount (GJ), $\mathrm{E}_{\mathrm{H}}$-produced heat amount (MWh).

\subsection{Neural Modelling}

A neural modelling process was carried out to check the correctness of the performed research and to indicate whether methane productivity can be predicted from the results of the measurements. The neural modeling process was carried out using the $\mathrm{H}_{2} \mathrm{O}$ program. Overall, 11 variables were involved in the modeling, of which 10 were input variables: flower, dry matter of the batch $[\mathrm{g}]$, fresh mass of the batch $[\mathrm{g}]$, dry organic matter of the batch $[\mathrm{g}]$, fresh mass of the feedstock $[\mathrm{g}]$, dry matter of the feedstock $[\mathrm{g}]$, dry organic matter of the feedstock $[\mathrm{g}]$, fresh mass of the inoculum $[\mathrm{g}]$, dry matter of the inoculum $[\mathrm{g}]$, and dry organic matter of the inoculum $[\mathrm{g}]$. There was one output variable: methane volume $\left[\mathrm{m}^{3}\right]$.

\section{Results}

\subsection{Calorific Value of Floricultural Waste}

The average values of the calorific value for each analyzed feedstock are summarized in Table 1. They were completely dried tulips, roses, chrysanthemums and sunflowers, which consisted of leaves, flowers and stems. Separated, dried, leafless stalks of these plants were also analyzed. In addition, the heat of combustion of dried, previously overfed, tulip shoots, which are waste in the production of planting material, was examined. The test was repeated for each feedstock until the difference between the results of the two most closely related tests was no more than $120 \mathrm{~kJ} / \mathrm{kg}$. Then, on the basis of the most similar measurements, the average value of the combustion heat of the given feedstock was calculated according to PN-81/G-04513 and rounded up to four significant digits. 
Table 1. Calorific value of floricultural waste.

\begin{tabular}{cc}
\hline Feedstock & Calorific Value (kJ/kg) \\
\hline Tulips with flowers & 15,210 \\
Stems and leaves of tulips & 16,890 \\
Roses & 17,720 \\
Stems of roses & 18,520 \\
Sunflowers & 17,640 \\
Stalks of sunflowers & 18,030 \\
Chrysanthemums & 15,560 \\
Stalks of chrysanthemums & 16,230 \\
\hline
\end{tabular}

The highest calorific values were obtained for dry stems of roses $(18,520 \mathrm{~kJ} / \mathrm{kg})$ and sunflowers $(18,030 \mathrm{~kJ} / \mathrm{kg})$. The lowest ones were obtained for dried tulips and chrysanthemums. The calorific values for these feedstocks were $15,210 \mathrm{~kJ} / \mathrm{kg}$ and $15,560 \mathrm{~kJ} / \mathrm{kg}$, respectively. Nevertheless, for solid biofuel production, complete drying of the feedstock is not recommended, even if it may affect the energy efficiency of the raw material.

\subsection{Feedstock and Inoculum Initial Parameters}

Just before the experiments for determination of biogas production, the physical and chemical properties of each analyzed feedstock sample were determined (Table 2).

Table 2. Results of physical and chemical properties for tested feedstock.

\begin{tabular}{ccc}
\hline Feedstock & Total Solids [\%] & Volatile Total Solids [\%] \\
\hline Mesophilic inoculum & 2.49 & 70.80 \\
Thermophilic inoculum & 2.69 & 64.47 \\
Tulips & 7.90 & 95.42 \\
Roses & 21.95 & 93.24 \\
Sunflowers & 21.44 & 93.53 \\
Chrysanthemums & 25.46 & 89.42 \\
\hline
\end{tabular}

The highest content of total solids was examined for chrysanthemums. Roses and sunflowers were characterized by lower results for this parameter. These amounted to $21.95 \%$ and $21.44 \%$ respectively. The lowest content of total solids among the analyzed floricultural waste was checked for tulips and did not reach $8 \%$.

However, the tulips were characterized by the highest content of volatile total solids, at the level of $95.42 \%$. For roses and sunflowers, also, the value of this parameter was very similar and approx. 2 percentage points lower than the result obtained for tulips. For chrysanthemums, the volatile total solids content was the lowest and amounted to $89.42 \%$. However, the differences between individual floricultural wastes were slight in relation to significant discrepancies in the total solids content between tulips and other kinds of floricultural waste. The content of volatile total solids in the inoculum was higher for mesophilic inocula compared to thermophilic ones.

\subsection{Biogas Production and Methane Production}

The amount of biogas produced during experiments was measured daily. On the basis of that data, the volume of biogas was calculated taking into account the daily correlation coefficient because biogas production was not measured every day at exactly the same time. The volumes of biomethane and other biogases produced as a result of anaerobic digestion were also recorded. The total production of these gases has been summed up.

The mesophilic anaerobic digestion of chaff from tulips lasted 23 days. Dynamic gas production was observed in the first days of fermentation. During this time, the largest daily production of 
methane was achieved on the fifth day. It amounted to $0.51 \mathrm{dm}^{3}$. From the sixth day, there was a systematic decrease in $\mathrm{CH}_{4}$ production. From the fourth to the twenty-third day, methane production exceeded its total daily production of all other gases by its volume.

Fermentation of macerate from tulips, which was also carried out under mesophilic conditions, as in the case of chaff from these plants, lasted 23 days. The largest amount of methane was created on the fifth day of testing, when daily production achieved $0.43 \mathrm{dm}^{3}$. From the sixth day, a decrease in production was measured. However, from the thirteenth day, the value of the daily production of $\mathrm{CH}_{4}$ began to increase and reached $0.26 \mathrm{dm}^{3}$ on the fifteenth day. Then, a systematic decrease in process production was observed to $0.02 \mathrm{dm}^{3}$ on the last day of the measurement. Only in the first four days of the fermentation other gases accounted for the majority in relation to the production of methane.

Both mesophilic and thermophilic anaerobic digestion of roses lasted 25 days. The maximum daily methane production for the mesophilic type was achieved on the fifth day of the experiment, when it reached $0.54 \mathrm{dm}^{3}$. A decrease in $\mathrm{CH}_{4}$ secretion was subsequently observed. On the last day, it was equal to $0.03 \mathrm{dm}^{3}$. Other gases than biomethane were created in the third week of the research $\left(0.66 \mathrm{dm}^{3}\right)$.

The maximum daily production of methane in the thermophilic type of anaerobic digestion from roses was observed relatively late. On the thirteenth day, it reached $0.32 \mathrm{dm}^{3}$. The whole experiment was characterized by instability, as the daily production of this gas fluctuated significantly. By the fifth day, its production increased to $0.15 \mathrm{dm}^{3}$. Then there was a two-day decline, followed by another increase and hesitation until the eighteenth day. From the next day, there was a significant decrease in the amount of produced methane. The production of other gases was similar. They accounted for most of the eleventh day of fermentation.

The chaff from sunflowers was feedstock for mesophilic and thermophilic fermentation. At that time, the highest daily production of $\mathrm{CH}_{4}$ was measured on the fourth day. It reached $0.44 \mathrm{dm}^{3}$ for fermentation in lower temperatures.

From the first to the fourth day its production dynamically increased, but then it dropped to $0.07 \mathrm{dm}^{3}$ on the tenth day of fermentation. By the end of the experiment, it fluctuated and ranged from $0.03 \mathrm{dm}^{3}$ to $0.07 \mathrm{dm}^{3}$ per day. Other gases showed a similar tendency. However, the most was produced in the first measurement day, when their volume amounted to $0.65 \mathrm{dm}^{3}$.

The thermophilic fermentation of chaff from sunflowers lasted 4 days shorter than mesophilic fermentation. On the fourth day, $0.28 \mathrm{dm}^{3}$ of methane was recorded, which was the highest result for this experiment. During the first four days, $\mathrm{CH}_{4}$ production was increased. Then, for three days, about $0.25 \mathrm{dm}^{3}$ of gas was produced daily. On the seventh day, there was a sharp drop to the level of $0.13 \mathrm{dm}^{3}$. The slow downward trend continued until the last, twenty-fifth day of fermentation. The largest production of other gases was achieved on the third day, when a volume of $0.38 \mathrm{dm}^{3}$ was measured. There was then a marked decrease in the content of produced biogas. From the seventh day, less than $0.01 \mathrm{dm}^{3}$ within a day was generated during the fermentation process.

Chaff from chrysanthemum was feedstock for mesophilic anaerobic digestion. It was decomposed in 29 days, like sunflowers. The daily production of methane was relatively small and reached its maximum on the seventh day of the process, reaching only $0.17 \mathrm{dm}^{3}$. In the following days, there was a slow decline in its production and then a slight increase. On the fourteenth day it was $0.08 \mathrm{dm}^{3}$, while in the eighteenth it was $0.1 \mathrm{dm}^{3}$. A decrease in $\mathrm{CH}_{4}$ emissions from the reactor was subsequently observed. On the last day of conducting measurements, it amounted to $0.02 \mathrm{dm}^{3}$. The other gases' production was the largest during the first day $\left(0.53 \mathrm{dm}^{3}\right)$ of the experiment. From the sixth day onwards, they were in a minority compared to methane.

Anaerobic digestion with the thermophilic type of chaff from chrysanthemum lasted 25 days, and therefore 4 days less than with the mesophilic one. The maximum methane production was achieved on the ninth day. It then amounted to $0.25 \mathrm{dm}^{3}$. Apart from several days from the eighth to eleventh day of research, the process was distinguished by a small production of this gas, as it was 
below $0.1 \mathrm{dm}^{3}$ for the remaining days. It was not until the ninth day that methane production exceeded the production of other gases by volume.

Such dynamics of fermentation indicated that, during first days of the biogas production process, the simple sugars were absorbed by bacteria [45]. During the next days, biogas was produced from other substances. Just after the beginning of the anaerobic digestion, biomethane production was lower than that of other gases, especially carbon, which is specific to the first stages of biogas production [46]. The process decreased until the 29th day, at which point it was finished.

The amounts of biogas and methane production from floricultural waste were summarized and calculated per 1 ton of each feedstock (Table 3). The results were determined on the basis of cumulated and averaged production of gases from bioreactors, including control sample results correction.

Table 3. Cumulated biogas and methane production from each analyzed feedstock.

\begin{tabular}{|c|c|c|c|c|c|c|c|c|}
\hline \multirow{2}{*}{ Feedstock } & \multirow{2}{*}{$\begin{array}{c}\text { Days of } \\
\text { Fermentation }\end{array}$} & \multirow[t]{2}{*}{$\begin{array}{c}\mathrm{CH}_{4} \\
\text { Content } \\
(\%)\end{array}$} & \multicolumn{2}{|c|}{$\begin{array}{c}\text { Fresh Mass } \\
\text { (m3/Mg of FM) }\end{array}$} & \multicolumn{2}{|c|}{$\begin{array}{l}\text { Total Solids } \\
\text { (m3/Mg of TS) }\end{array}$} & \multicolumn{2}{|c|}{$\begin{array}{l}\text { Volatile Total Solids } \\
\text { (m3/Mg of VTS) }\end{array}$} \\
\hline & & & $\begin{array}{c}\text { Cumulated } \\
\mathrm{CH}_{4}\end{array}$ & $\begin{array}{l}\text { Cumulated } \\
\text { Biogas }\end{array}$ & $\begin{array}{c}\text { Cumulated } \\
\mathrm{CH}_{4}\end{array}$ & $\begin{array}{c}\text { Cumulated } \\
\text { Biogas }\end{array}$ & $\begin{array}{c}\text { Cumulated } \\
\mathrm{CH}_{4}\end{array}$ & $\begin{array}{c}\text { Cumulated } \\
\text { Biogas }\end{array}$ \\
\hline $\begin{array}{l}\text { Tulip chaff } \\
\text { under } \\
\text { mesophilic } \\
\text { conditions }\end{array}$ & 23 & 54.37 & 28.30 & 52.04 & 358.18 & 658.83 & 375.37 & 690.39 \\
\hline $\begin{array}{l}\text { Tulip macerate } \\
\text { under } \\
\text { mesophilic } \\
\text { conditions }\end{array}$ & 23 & 53.07 & 27.98 & 52.72 & 354.14 & 667.30 & 371.14 & 699.33 \\
\hline $\begin{array}{l}\text { Roses under } \\
\text { mesophilic } \\
\text { conditions }\end{array}$ & 25 & 49.92 & 61.28 & 122.76 & 294.17 & 589.28 & 316.15 & 633.35 \\
\hline $\begin{array}{l}\text { Roses under } \\
\text { thermophilic } \\
\text { conditions }\end{array}$ & 25 & 56.68 & 62.26 & 109.84 & 283.65 & 500.44 & 304.22 & 536.73 \\
\hline $\begin{array}{l}\text { Sunflowers } \\
\text { under } \\
\text { mesophilic } \\
\text { conditions }\end{array}$ & 29 & 49.27 & 53.31 & 108.22 & 248.70 & 504.80 & 278.14 & 564.56 \\
\hline $\begin{array}{l}\text { Sunflowers } \\
\text { under } \\
\text { thermophilic } \\
\text { conditions }\end{array}$ & 25 & 47.83 & 40.79 & 85.28 & 190.29 & 397.83 & 212.82 & 444.92 \\
\hline $\begin{array}{l}\text { Chrysanthemu } \\
\text { under } \\
\text { mesophilic } \\
\text { conditions }\end{array}$ & 29 & 47.59 & 59.05 & 124.08 & 231.92 & 487.32 & 247.95 & 521.00 \\
\hline $\begin{array}{l}\text { Chrysanthemu } \\
\text { under } \\
\text { thermophilic } \\
\text { conditions }\end{array}$ & 25 & 40.64 & 35.11 & 86.40 & 137.89 & 339.32 & 147.42 & 362.78 \\
\hline
\end{tabular}

Based on the analyzed floricultural waste, the highest methane content in the produced biogas was reached by thermophilic fermentation of roses (56.68\%). All of the remaining feedstock was characterized by a lower and simultaneously similar content of $\mathrm{CH}_{4}$ in biogas. The value for tulips, depending on the degree of fragmentation, was $53-54 \%$. However, for sunflowers, regardless of the type of anaerobic digestion, it was approximately $48-49 \%$. This was similar to the result obtained for chaff from roses and chrysanthemums during decomposition under mesophilic conditions. The lowest methane content in biogas (40.64\%) was obtained from chrysanthemum chaff under thermophilic conditions of fermentation.

Moreover, floricultural waste was characterized by a generally high methane content. However, for chicken manure, its content reached from $46 \%$ to $57 \%$ [ 47,48$]$ and it was $68-69 \%$ for fish waste [49]. Nevertheless, the methane content of waste from floriculture is comparable with cattle manure $(50-60 \%)$ 
and pig manure $60 \%[6,11]$. These biogases' production stems from the fact that animal waste contains more proteins and fats, which are generally better chemical compounds for biogas production. On the other hand, some of the floricultural waste is characterized by higher methane content compared to maize straw silage (52\%) [40], breeding waste from sericulture (52\%) [11] and bread waste (53\%) [49].

The obtained results were also calculated per ton of fresh mass of each feedstock. The most effective wastes for biogas production were chrysanthemums, roses and sunflowers under mesophilic anaerobic digestion. The lowest result was obtained for tulips. In this case, regardless of the feedstock fragmentation, more than two times less biogas was obtained. However, taking into account only the production of methane, the highest productivity was by roses.

Analyzing the production of biogas calculated per ton of total solids of each feedstock, it was found that the most biogas can be obtained from tulips and the least from chrysanthemums, regardless of the technology used. The production of methane is analogous. The results are mainly influenced by the amount of TS in biomass. Although there are high production values per TS unit, it has to be considered that lower TS content required a higher amount of biomass and higher volumes to process it.

Macerated tulips gave the highest result per ton of dry organic matter. On the other hand, chrysanthemums under thermophilic fermentation conditions turned out to be the least efficient in this case. For this feedstock, the amount of biogas was almost two times lower compared to tulips. Methane production was characterized by a similar discrepancy between those species.

Based on the obtained research results, it can be further stated that the fermentation of the same feedstock under mesophilic conditions lasted slightly longer or the same number of days compared to anaerobic digestion under thermophilic conditions. As regards the percentage of methane content in the produced biogas, only in the case of the fermentation of roses carried out at higher temperatures was the process more effective. Moreover, for sunflowers and chrysanthemums, more biomethane was obtained in the mesophilic type than in the thermophilic anaerobic digestion. Furthermore, the mesophilic process operating cost is much lower than thermophilic method because it needs much less energy input to maintain the optimal temperature. Mesophilic fermentation is also less sensitive to environmental changes in the process [50].

More than $80 \%$ of biomethane production was accumulated during the first 15 days of the research for each floricultural waste, except during thermophilic fermentation of roses. In comparison, for maize straw silage, it lasts 15 days under thermophilic conditions and 17 days under mesophilic ones to provide the same result [51].

Moreover, the HRT for floricultural waste was shorter compared to maize straw silage [40] but longer than for breeding waste and excrement from sericulture, which were analyzed according to the same methods and in standard conditions [11]. The investigated HRT was shorter compared to microalgal biomass, for which it lasts approx. 30 days and depends on the species [52]. Additionally, the HRT results were comparable or shorter than for chicken manure (HRT from 30 to 35 days) $[53,54]$ and pig slurry, which was co-digested with olive pomace oil (24 days) [11,55].

The neural modelling process is carried out individually for empirically acquired data. Depending on the experience and available equipment, different parameters are obtained-not to mention the difference in the parameters of the examined object. Therefore, comparing models from different works is quite problematic. The authors use different input variables, network learning techniques and models themselves. Among the works that can be referred to is the work of the Pérez-Zárate team [56], where, for traditional modelling methods, the quality of the network was $80 \%$, and the Dach team [57], where, for traditional modelling methods, the quality of the network was $73 \%$. It should be noted that the models in these works differ in the type of learning, structure and input variables.

\subsection{Energy Production}

Based on the efficiencies of biomethane and biogas of floricultural waste, the amount of electricity and the amount of heat produced by the biogas combustion in a cogeneration system were calculated 
in three variants: Per $1 \mathrm{Mg}$ of fresh mass (FM), total solids (TS) and volatile total solids (VTS) (Table 4). The produced heat amount was also converted to GJ.

Table 4. Energy production of each analyzed feedstock.

\begin{tabular}{|c|c|c|c|c|}
\hline Feedstock & $\begin{array}{c}\text { Variants } \\
\text { Per } 1 \mathrm{Mg} \text { of }\end{array}$ & $\begin{array}{l}\text { Produced Energy } \\
\text { Amount (MWh) }\end{array}$ & $\begin{array}{l}\text { Produced Heat } \\
\text { Amount (MWh) }\end{array}$ & $\begin{array}{c}\text { Produced Heat } \\
\text { Amount (GJ) }\end{array}$ \\
\hline \multirow{3}{*}{$\begin{array}{l}\text { Tulip chaff under } \\
\text { mesophilic conditions }\end{array}$} & $\mathrm{FM}$ & 0.21 & 0.21 & 0.77 \\
\hline & TS & 2.66 & 2.72 & 9.92 \\
\hline & VTS & 2.79 & 2.85 & 10.40 \\
\hline \multirow{3}{*}{$\begin{array}{l}\text { Tulip macerate under } \\
\text { mesophilic conditions }\end{array}$} & $\mathrm{FM}$ & 0.21 & 0.22 & 0.79 \\
\hline & $\mathrm{TS}$ & 2.69 & 2.75 & 10.05 \\
\hline & VTS & 2.82 & 2.89 & 10.53 \\
\hline \multirow{3}{*}{$\begin{array}{l}\text { Roses under } \\
\text { thermophilic conditions }\end{array}$} & $\mathrm{FM}$ & 0.50 & 0.51 & 1.85 \\
\hline & TS & 2.37 & 2.43 & 8.87 \\
\hline & VTS & 2.56 & 2.61 & 9.54 \\
\hline \multirow{3}{*}{$\begin{array}{l}\text { Roses under } \\
\text { mesophilic conditions }\end{array}$} & $\mathrm{FM}$ & 0.44 & 0.45 & 1.65 \\
\hline & $\mathrm{TS}$ & 2.02 & 2.07 & 7.54 \\
\hline & VTS & 2.17 & 2.21 & 8.08 \\
\hline \multirow{3}{*}{$\begin{array}{l}\text { Sunflowers under } \\
\text { mesophilic conditions }\end{array}$} & $\mathrm{FM}$ & 0.44 & 0.45 & 1.63 \\
\hline & TS & 2.04 & 2.08 & 7.60 \\
\hline & VTS & 2.28 & 2.33 & 8.50 \\
\hline \multirow{3}{*}{$\begin{array}{l}\text { Sunflowers under } \\
\text { thermophilic conditions }\end{array}$} & FM & 0.34 & 0.35 & 1.28 \\
\hline & TS & 1.61 & 1.64 & 5.99 \\
\hline & VTS & 1.80 & 1.84 & 6.70 \\
\hline \multirow{3}{*}{$\begin{array}{l}\text { Chrysanthemums under } \\
\text { mesophilic conditions }\end{array}$} & $\mathrm{FM}$ & 0.50 & 0.51 & 1.87 \\
\hline & TS & 1.97 & 2.01 & 7.34 \\
\hline & VTS & 2.10 & 2.15 & 7.85 \\
\hline \multirow{3}{*}{$\begin{array}{l}\text { Chrysanthemums under } \\
\text { thermophilic conditions }\end{array}$} & $\mathrm{FM}$ & 0.35 & 0.36 & 1.30 \\
\hline & $\mathrm{TS}$ & 1.37 & 1.40 & 5.11 \\
\hline & VTS & 1.46 & 1.50 & 5.46 \\
\hline
\end{tabular}

Mesophilic fermentation of roses and chrysanthemums was characterized by the highest energy production ( $0.5 \mathrm{MWh} / \mathrm{Mg}$ of FM) compared to the other analyzed wastes from floriculture. One ton of fresh biomass can also give 1.85 and $1.87 \mathrm{GJ}$ of heat, respectively. The worst result was achieved for tulips. Those parameters were the lowest, regardless of the degree of fragmentation of the feedstock.

However, if one were to calculate the energy production according to the total solids, tulip chaff and macerate gave the largest production of heat from one ton of dry matter of feedstock (till 10.05 GJ/Mg of TS). The smallest production was found for thermophilic fermentation of chrysanthemums (5.11 GJ/1 Mg of TS).

Similar results have been received for calculations per one ton of volatile total solids of each feedstock. The largest production of electricity would be possible from tulips (till 10.53 GJ/Mg of VTS) and the smallest from thermophilic fermentation of chrysanthemums (5.46 GJ/Mg of VTS).

Generally, significant differences were observed between received results calculated per one ton of fresh mass compared to per one ton of total solids and volatile total solids. This was a result of the relatively high content of water in fresh biomass of floricultural waste.

\subsection{Result of Neural Modelling Process}

The learning process was determined for 10,000 epochs. The rest of the parameters were left unchanged. The model was made on flowers: roses, sunflowers, chrysanthemums and tulips. Flower names have been replaced by numerical values (roses-1, chrysanthemums-2, sunflowers-3, tulips-4). In the process of generating the neural model, the sensitivity analysis of individual variables was carried out.

The training set contained 14 cases. This is a very small number, but deep neural networks have the ability to use redundancy of cases and so a small number of cases is not a problem and does not 
affect network performance. The data used in the process of learning the neural model was randomly selected by the simulator from the whole set. The model learning chart is presented in Figure 1. The network characteristics are presented in Table 5

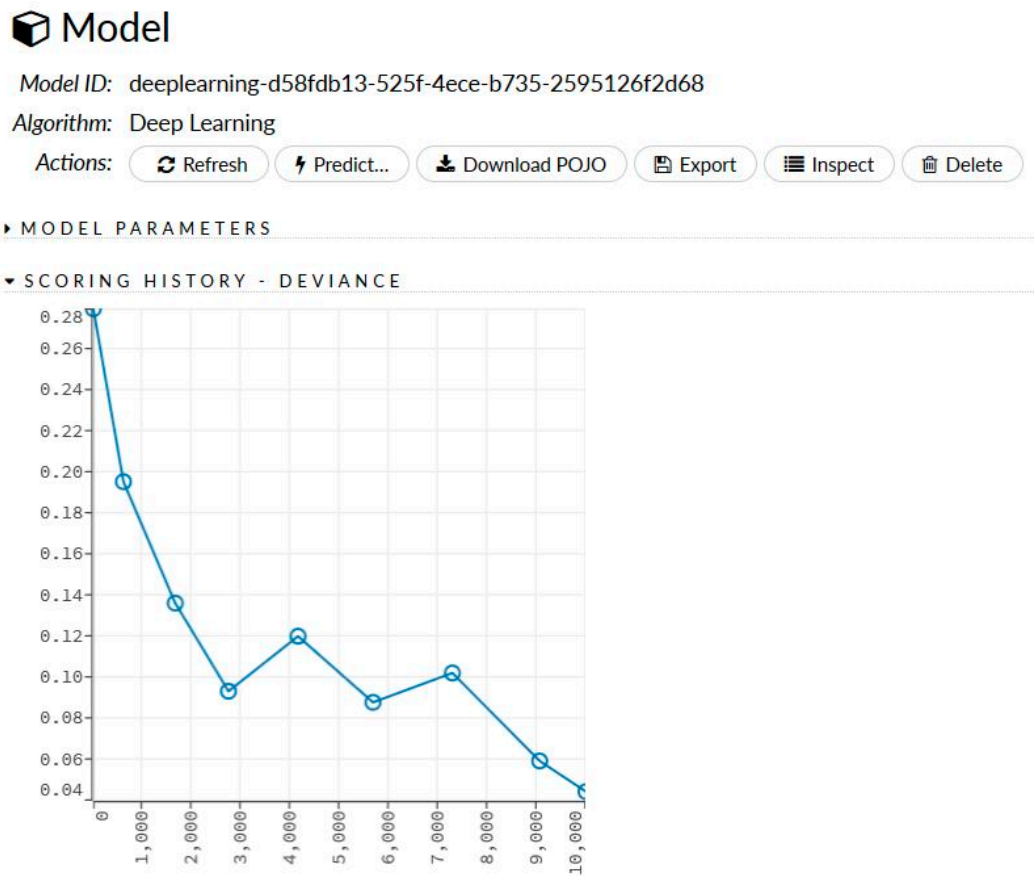

Figure 1. Screenshot of the learning process in $\mathrm{H}_{2} \mathrm{O}$.

Table 5. Network characteristics.

\begin{tabular}{cc}
\hline \multicolumn{2}{c}{ Network Characteristics } \\
\hline MSE & 0.004186 \\
RMSE & 0.064700 \\
nobs & 14 \\
r2 & 0.991181 \\
mean_residual_deviance & 0.004186 \\
mae & 0.044468 \\
\hline
\end{tabular}

MSE-Mean Squared Error, RMSE—Root Mean Squared Error, nobs-the number of training cases, r2-coefficient of determination, mean residual deviance, mae-mean absolute error.

The network operation parameters indicate a very high match factor r2 0.991181 and low MSE and RMSE error values-0.004186 and 0.064700 .

The most important variables for the model operation, in order:

1. fresh_mass_of_the_batch_[g],

2. dry_organic_matter_of_the_feedstock_[g],

3. dry_matter_of_the_feedstock_[g],

4. dry_matter_of_the_inoculum_[g],

5. dry_matter_of_the_batch_[g],

6. dry_organic_matter_of_the_batch_[g],

7. fresh_mass_of_the_feedstock_[g],

8. flower,

9. fresh_,mass_of_the_inoculum_[g],

10. dry_matter_of_the_inoculum_[g]. 


\section{Conclusions}

All of the fermentation processes ran smoothly, with no inhibition or $\mathrm{pH}$ interference. Each of the examined types of feedstock decomposed relatively fast. The HRT of all investigated species ranged from 23 to 29 days, which is comparable with the HRT of the biomass commonly used in the anaerobic digestion process.

The obtained results proved that floricultural waste has good biogas potential. Owing to the time of anaerobic digestion of analyzed materials, biomethane production from floricultural waste is more efficient compared to commonly used agricultural feedstock. Moreover, the analyzed feedstock had comparable methane content compared to chicken, cattle or pig manure (except chrysanthemum chaff under thermophilic conditions of fermentation). In addition, the generated neural model shows high efficiency in forecasting methane production. Its coefficient of determination is 0.991181 and its RMSE error is 0.064700 .

Producing solid biofuels or biogas from floricultural waste may be a good source of additional income for farmers. Furthermore, re-using it, rather than storing it, allows for ecological and energetic management of floricultural waste.

Author Contributions: Conceptualization, J.F., M.Z., J.D., W.C., J.P.; methodology, M.Z., J.D.; software, M.Z.; validation, J.F., M.Z., J.D., W.C.; formal analysis, J.F., M.Z., J.P.; investigation, J.F., M.Z., W.C.; resources, J.F., M.Z., W.C.; data curation, J.F., M.Z., J.D.; writing—original draft preparation, J.F., M.Z., J.D., W.C., J.P.; writing-review and editing, J.F., M.Z., J.D., W.C., J.P.; visualization, J.F. and M.Z.; supervision, project administration and funding acquisition, J.D., J.P. All authors have read and agreed to the published version of the manuscript.

Funding: This research received no external funding.

Conflicts of Interest: The authors declare no conflict of interest.

\section{References}

1. Available online: https://www.nytimes.com/2020/04/12/world/europe/netherlands-tulips-coronavirus.html (accessed on 13 April 2020).

2. Council of the European Union. Directive 2009/28/EC of the European Parliament and of the Council of 23 April 2009 on the Promotion of the Use of Energy from Renewable Sources and Amending and Subsequently Repealing Directives 2001/77/EC and 2003/30/EC; Council of the European Union: Brussels, Belgium, 2009; pp. 16-62.

3. Dole, J.M.; Wilkins, H.F. Floriculture: Principles and Species; Prentice-Hall Inc.: Upper Saddle River, NJ, USA, 1999; p. 613.

4. Shehrawat, P.S.; Sindhu, N. Agricultural waste utilization for healthy environment and sustainable lifestyle. Ann. Agric. Biol. Res. 2015, 20, 110-114.

5. Getu, M. Ethiopian floriculture and its impact on the environment. Mizan Law Rev. 2009, 3, 240-270. [CrossRef]

6. Dobre, P.; Nicolae, F.; Matei, F. Main factors affecting biogas production-An overview. Rom. Biotech. Lett. 2014, 19, 9283-9296.

7. Mao, C.; Feng, Y.; Wang, X.; Ren, G. Review on research achievements of biogas from anaerobic digestion. Renew. Sustain. Energy Rev. 2015, 45, 540-550. [CrossRef]

8. Shin, H.S.; Youn, J.H.; Kim, S.H. Hydrogen production from food waste in anaerobic mesophilic and thermophilic acidogenesis. Int. J. Hydrog. Energy 2004, 29, 1355-1363. [CrossRef]

9. Czerwińska, E.; Kalinowska, K. Conditions for conducting the methane fermentation process in a biogas plant. Agric. Hortic. Tech. 2014, 2, 12-14. (In Polish)

10. Jha, M.N.; Jha, S.; Chourasia, S.K. Agroecology of Agromicrobes. In Agroecology Ecosystems and Sustainability; Benkeblia, N., Ed.; CRC Press: Boca Raton, FL, USA, 2015; pp. 81-102.

11. Łochyńska, M.; Frankowski, J. The biogas production potential from silkworm waste. Waste Manag. 2018, 79, 564-570. [CrossRef] [PubMed] 
12. Polish Standards PN-75/C-04616/01. Wydawnictwo Normalizacyjne. Warszawa. Oznaczanie suchej masy osadu i substancji organicznych. Woda i ścieki. Badania specjalne osadów. Oznaczanie zawartości wody, suchej masy, substancji organicznych i substancji mineralnych w osadach ściekowych [in Polish]: Determination of dry matter of sludge and organic substances. Water and sewage. Special sludge tests. Determination of water content, dry matter, organic substances and mineral substances in sewage sludge.

13. Polish Standards PN-Z-15011-3:2001. Kompost z odpadów komunalnych. Oznaczanie: pH, zawartości substancji organicznej, węgla organicznego, azotu, fosforu i potasu [in Polish]: Municipal waste compost. Determination of: PH, organic matter content, organic carbon, nitrogen, phosphorus and potassium.

14. Iraji, M.; Tosinia, A. Classification Tomatoes on Machine Vision with Fuzzy the Mamdani Inference, Adaptive Neuro Fuzzy Inference System Based (Anfis-Sugeno). Aust. J. Basic Appl. Sci. 2011, 5, 846-853.

15. Mutlu, A.C.; Boyaci, I.H.; Genis, H.E.; Ozturk, R.; Basaran-Akgul, N.; Sanal, T.; Evlice, A.K. Prediction of wheat quality parameters using near-infrared spectroscopy and artificial neural networks. Eur. Food Res. Technol. 2011, 233, 267-274. [CrossRef]

16. Boniecki, P.; Dach, J.; Mueller, W.; Koszela, K.; Przybył, J.; Pilarski, K.; Olszewski, T. Neural prediction of heat loss in the pig manure composting process. Appl. Therm. Eng. 2013, 58, 650-655. [CrossRef]

17. Boniecki, P.; Piekarska-Boniecka, H.; Koszela, K.; Zaborowicz, M.; Przybył, K.; Wojcieszak, D.; Zbytek, Z.; Ludwiczak, A.; Przybylak, A.; Lewicki, A. Neural classifier in the estimation process of maturity of selected varieties of apples. In Proceedings of the Seventh International Conference on Digital Image Processing (ICDIP 2015), Kuala Lumpur, Malaysia, 6 July 2015. [CrossRef]

18. Martelo-Vidal, M.J.; Vázquez, M. Application of artificial neural networks coupled to UV-VIS-NIR spectroscopy for the rapid quantification of wine compounds in aqueous mixtures. CyTA J. Food 2015, 13, 32-39. [CrossRef]

19. Przybylak, A.; Boniecki, P.; Koszela, K.; Ludwiczak, A.; Zaborowicz, M.; Lisiak, D.; Stanisz, M.; Ślósarz, P. Estimation of intramuscular level of marbling among Whiteheaded Mutton Sheep lambs. J. Food Eng. 2016, 168, 199-204. [CrossRef]

20. Rafiq, A.; Makroo, H.A.; Hazarika, M.K. Artificial Neural Network-Based Image Analysis for Evaluation of Quality Attributes of Agricultural Produce. J. Food Process. Preserv. 2016, 40, 1010-1019. [CrossRef]

21. Aghajani, N.; Kashaninejad, M.; Dehghani, A.A.; Daraei, G.A. Comparison between artificial neural networks and mathematical models for moisture ratio estimation in two varieties of green malt. Qual. Assur. Saf. Crop. Foods 2012, 4, 93-101. [CrossRef]

22. Zaborowicz, M.; Boniecki, P.; Koszela, K.; Przybylak, A.; Przybył, J. Application of neural image analysis in evaluating the quality of greenhouse tomatoes. Sci. Hortic. 2017, 218, 222-229. [CrossRef]

23. Sidelko, R.; Janowska, B.; Walendzik, B.; Siebielska, I. Two composting phases running in different process conditions timing relationship. Bioresour. Technol. 2010, 101, 6692-6698. [CrossRef] [PubMed]

24. Bayram, A.; Kankal, M.; Ozsahin, T.S.; Saka, F. Estimation of the Carbon to Nitrogen (C:N) Ratio in Compostable Solid Waste Using Artificial Neural Networks. Fresenius Environ. Bull. 2011, 20, 3250-3257.

25. Boniecki, P.; Nowakowski, K.; Ślósarz, P.; Dach, J.; Pilarski, K. Neural Image Analysis for Estimating Aerobic and Anaerobic Decomposition of Organic Matter Based on The Example of Straw Decomposition. In Proceedings of the Fourth International Conference on Digital Image Processing (ICDIP 2012), Kuala Lumpur, Malaysia, 8 June 2012; Volume 8334. [CrossRef]

26. Wojcieszak, D.; Przybył, J.; Lewicki, A.; Ludwiczak, A.; Przybylak, A.; Boniecki, P.; Koszela, K.; Zaborowicz, M.; Przybył, K.; Witaszek, K. Use of neural image analysis methods in the process of determine the dry matter content in the compost. In Proceedings of the Seventh International Conference on Digital Image Processing (ICDIP 2015), Kuala Lumpur, Malaysia, 6 July 2015; Volume 963118. [CrossRef]

27. Yildiz, S.; Degirmenci, M. Estimation of Oxygen Exchange during Treatment Sludge Composting through Multiple Regression and Artificial Neural Networks (Estimation of Oxygen Exchange during Composting). Int. J. Environ. Res. 2015, 9, 1173-1182.

28. Chitsan, L.; Chih-Chiang, W.; Chia-Cheng, T. Prediction of Influential Operational Compost Parameters for Monitoring Composting Process. Environ. Eng. Sci. 2016, 33, 494-506. [CrossRef]

29. Zaborowicz, M.; Wojcieszak, D.; Górna, K.; Kujawa, S.; Kozłowski, R.J.; Przybył, K.; Mioduszewska, N.; Idziaszek, P.; Boniecki, P. Determination of dry matter content in composted material based on digital images of compost taken under mixed visible and UV-A light. In Proceedings of the Eighth International Conference on Digital Image Processing (ICDIP 2016), Kuala Lumpur, Malaysia, 29 August 2016. [CrossRef] 
30. Zou, H.F.; Xia, G.P.; Yang, F.T.; Wang, H.Y. An investigation and comparison of artificial neural network and time series models for Chinese food grain price forecasting. Neurocomputing 2007, 70, 2913-2923. [CrossRef]

31. Cervone, G.; Clemente-Harding, L.; Alessandrini, S.; Monache, L.D. Short-term photovoltaic power forecasting using Artificial Neural Networks and an Analog Ensemble. Renew. Energy 2017, 108, $274-286$. [CrossRef]

32. Qiu, M.; Song, Y. Predicting the Direction of Stock Market Index Movement Using an Optimized Artificial Neural Network Model. PLoS ONE 2016, 11, e0155133. [CrossRef] [PubMed]

33. Bugała, A.; Zaborowicz, M.; Boniecki, P.; Janczak, D.; Koszela, K.; Czekała, W.; Lewicki, A. Short-term forecast of generation of electric energy in photovoltaic systems. Renew. Sustain. Energy Rev. 2018, 81, 306-312. [CrossRef]

34. Hinton, G.; Osindero, S.Y.-W. A Fast Learning Algorithm for Deep Belief Nets. Neural Comput. 2006, 18, 1527-1554. [CrossRef] [PubMed]

35. Ioannou, Y. Restricted Connectivity in Deep Neural Networks; University of Cambridge: Cambridge, UK, 2017; Available online: https://yani.io/annou/presentations/kaistpresentation.pdf (accessed on 15 March 2020).

36. Waliszewska, B.; Zborowska, M.; Pradzynski, W.; Kominer, A. Chemical composition and gross calorific value of selected Salix hybrids. In Wood Structure and Properties; Trans Tech Publications Ltd.: Stafa-Zurich, Switzerland, 2006; pp. 171-173.

37. Krzyżaniak, M.; Stolarski, M.J.; Waliszewska, B.; Szczukowski, S.; Tworkowski, J.; Załuski, D.; Śnieg, M. Willow biomass as feedstock for an integrated multi-product biorefinery. Ind. Crop. Prod. 2014, 58, 230-237. [CrossRef]

38. Waliszewska, B.; Duda, M.; Waliszewska, H.; Spek-Dźwigała, A.; Sieradzka, A. The gross calorific value and the net calorific value of selected exotic wood species. Ann. Wars. Univ. Life Sci. SGGW For. Wood Technol. 2016, 96, 226-229.

39. Szambelan, K.; Nowak, J.; Frankowski, J.; Szwengiel, A.; Jeleń, H.; Burczyk, H. The comprehensive analysis of sorghum cultivated in Poland for energy purposes: Separate hydrolysis and fermentation and simultaneous saccharification and fermentation methods and their impact on bioethanol effectiveness and volatile by-products from the grain and the energy potential of sorghum straw. Bioresour. Technol. 2018, 250, 750-757.

40. Cieślik, M.; Dach, J.; Lewicki, A.; Smurzyńska, A.; Janczak, D.; Pawlicka-Kaczorowska, J.; Boniecki, P.; Cyplik, P.; Czekała, W.; Jóźwiakowski, K. Methane fermentation of the maize straw silage under meso- and thermophilic conditions. Energy 2016, 115, 1495-1502. [CrossRef]

41. Dach, J.; Koszela, K.; Boniecki, P.; Zaborowicz, M.; Lewicki, A.; Czekała, W.; Skwarcz, J.; Qiao, W.; Piekarska-Boniecka, H.; Białobrzewski, I. The use of neural modelling to estimate the methane production from slurry fermentation processes. Renew. Sustain. Energy Rev. 2016, 56, 603-610. [CrossRef]

42. Dach, J. Energetic and economic efficiency of agricultural biogas plant working with different substrates. J. Res. Appl. Agric. Engng. 2016, 61, 72-76.

43. Kasprzycka, A.; Lalak, J.; Tys, J. Impact of fragmentation on biogas production from plant biomass. Acta Agrophys. 2015, 22, 139-149.

44. Dach, J.; Boniecki, P.; Przybył, J.; Janczak, D.; Lewicki, A.; Czekała, W.; Witaszek, K.; Rodríguez Carmona, P.C.; Cieślik, M. Energetic efficiency analysis of the agricultural biogas plant in 250kWe experimental installation. Energy 2014, 69, 34-38. [CrossRef]

45. Ni, B.J.; Batstone, D.; Zhao, B.H.; Yu, H.Q. Microbial internal storage alters the carbon transformation in dynamic anaerobic fermentation. Environ. Sci. Technol. 2015, 49, 9159-9167. [CrossRef] [PubMed]

46. Zhang, C.; Su, H.; Baeyens, J.; Tan, T. Reviewing the anaerobic digestion of food waste for biogas production. Renew. Sustain. Energy Rev. 2014, 38, 383-392. [CrossRef]

47. Braeutigam, P.; Franke, M.; Ondruschka, B. Effect of ultrasound amplitude and reaction time on the anaerobic fermentation of chicken manure for biogas production. Biomass. Bioenerg. 2014, 63, 109-113. [CrossRef]

48. Lewicki, A.; Kozłowski, K.; Pietrowski, M.; Zbytek, Z. Methane fermentation of chicken droppings. J. Res. Appl. Agric. Engng. 2016, 61, 28-30.

49. Kafle, G.K.; Kim, S.H.; Sung, K.I. Ensiling of fish industry waste for biogas production: A lab scale evaluation of biochemical methane potential (BMP) and kinetics. Bioresour. Technol. 2013, 127, 326-336. [CrossRef]

50. Chasnyk, O.; Sołowski, G.; Shkarupa, O. Historical, technical and economic aspects of biogas development: Case of Poland and Ukraine. Renew. Sustain. Energy Rev. 2015, 52, 227-239. [CrossRef] 
51. Igliński, B.; Buczkowski, R.; Cichosz, M. Biogas production in Poland-Current state, potential and perspectives. Renew. Sustain. Energy Rev. 2015, 50, 686-695. [CrossRef]

52. Kwietniewska, E.; Tys, J. Process characteristics, inhibition factors and methane yields of anaerobic digestion process, with particular focus on microalgal biomass fermentation. Renew. Sustain. Energy Rev. 2014, 34, 491-500. [CrossRef]

53. Niu, Q.; Hojo, T.; Qiao, W.; Qiang, H.; Li, Y.Y. Characterization of methanogenesis, acidogenesis and hydrolysis in thermophilic methane fermentation of chicken manure. Chem. Eng. J. 2014, 244, 587-596. [CrossRef]

54. Wang, M.; Sun, X.; Li, P.; Yin, L.; Liu, D.; Zhang, Y.; Li, W.; Zheng, G. A novel alternate feeding mode for semi-continuous anaerobic co-digestion of food waste with chicken manure. Bioresour. Technol. 2014, 164, 309-314. [CrossRef] [PubMed]

55. Orive, M.; Cebrián, M.; Zufía, J. Techno-economic anaerobic co-digestion feasibility study for two-phase olive oil mill pomace and pig slurry. Renew. Energy 2016, 97, 532-540. [CrossRef]

56. Pérez-Zárate, D.; Santoyo, E.; Acevedo-Anicasio, A.; Díaz-González, L.; García-López, C. Evaluation of artificial neural networks for the prediction of deep reservoir temperatures using the gas-phase composition of geothermal fluids. Comput. Geosci. 2019, 129, 49-68. [CrossRef]

57. Kowalczyk-Juśko, A.; Pochwatka, P.; Zaborowicz, M.; Czekała, W.; Mazurkiewicz, J.; Mazur, A.; Janczak, D.; Marczuk, A. Energy value estimation of silages for substrate in biogas plants usingan artificial neural network. Energy 2020, 202, 117729. [CrossRef]

(C) 2020 by the authors. Licensee MDPI, Basel, Switzerland. This article is an open access article distributed under the terms and conditions of the Creative Commons Attribution (CC BY) license (http://creativecommons.org/licenses/by/4.0/). 